\title{
A RED WATER CAUSED BY MESODINIUM RUBRUM ON THE COAST OF SANTA CATARINA, SOUTHERN BRAZIL
}

\author{
Luis Antônio de Oliveira Proença \\ Universidade do Vale do Itajaí \\ Centro de Ciências Tecnológicas da Terra e do Mar, CTTMar \\ (Rua Uruguai, 458, 88302-202 - Centro Itajaí, SC, Brasil) \\ proenca@cttmar.univali.br
}

Descritores: M. rubrum, P. micans, Sta. Catarina, Fitoplâncton, Floração.

Descriptors: M. rubrum, P. micans, Santa Catarina, Phytoplankton, Bloom.

Red waters caused by non-toxic blooms of the planktonic, phototrophic ciliate Mesodinium rubrum (Lohmann) have been reported to occur around the world, from estuarine areas to up upwelling systems. These blooms show high values of chlorophyll $a$ concentration, up to $1000 \mu \mathrm{g} \mathrm{l}^{-1}$ and equally high rates of primary production (Taylor et al., 1971, Lindholm, 1985). M. rubrum is an obligate phototroph due to the presence of a cryptomonad as an endosymbiot (Hibberd, 1977). Although the strong symbiosis between the ciliate and its host assures an autotrophic function, in general it is not commonly included as a phytoplankter. On the other hand, studies of the overall phytoplankton assemblage have shown that M. rubrum is an important community member in coastal ecosystems (Crawford, 1989). Thus, in spite of this ciliate being a very conspicuous and common species, most of the information about its distribution or its role in the plankton is based on opportunistic observation during bloom events.

$M$. rubrum is a common species along the southern Brazilian coast (Odebrecht \& Garcia, 1998). In the Patos Lagoon, an estuarine environment, $M$. rubrum can be found all year around and can dominate the community with densities up to $1.3 \times 10^{5}$ cell $l^{-1}$ (Abreu, 1992). Along the coast of São Paulo, a highly constrained subsurface red water of $M$. rubrum was observed, in association with calm and sunny weather (Owen et al., 1992). On the Santa Catarina coast, M. rubrum was frequently described as occurring in low densities in the Conceição lagoon, being more important in autumn and winter months (Odebrecht, 1988). This paper reports an episodic red water event caused by $M$. rubrum on the northern coast of Santa Catarina.

The northern coast of Santa Catarina is characterized by the presence of several coastal features, such as shoal bights, estuaries, lagoons and sandy beaches. Three main water masses occur in the region. The extension of the Coastal Water, with low salinities $(<34)$ and temperatures varying from 19 to $28^{\circ} \mathrm{C}$, is influenced by fresh water runoff. The Shelf Water (SW) has higher temperature and salinities (> 35) and occurs farther off the coast. The South Atlantic Central Water (SACW) is a colder, saltier and deeper water mass and is observed closer to the surface in the summer and spring (Schetinni et al., 1999). The local major fresh water input, with an average flow of $247 \mathrm{~m}^{3}$ $\mathrm{s}^{-1}$, comes form the Itajaí-Açu river that forms a partially stratified estuary (Fig. 1). Under some conditions, a very conspicuous plume extends from the Itajaí-Açu river mouth forming important gradients of salinity, nutrients, suspended matter, phytoplankton biomass and other factors (Schettini et al., 1998). Previous survey of phytoplankton biomass in six bight used for mussel culture, have showed a moderate trophic grade, with values ranging from less than 1 to about $11 \mu \mathrm{g} \mathrm{l}^{-1}$.

The red water was first noticed on the $16^{\text {th }}$ of August 2001 at the mouth of the Itajaí-Açu River and water samples were taken in the following day, on $17^{\text {th }}$. Samples were also collected one week later, on August $24^{\text {th }}$ after the passage of a cold frontal system, when the red water had disappeared. Sampling sites and frequency were determined in an opportunistic way to characterize the event. During the red water episode, five sites were sampled using a small boat: two inside the red water (\#Rw1 and \#Rw2) and tree outside (two inside the river, \#1 and \#2) (Fig. 1). On August $17^{\text {th }}$ water for chlorophyll $a(\mathrm{Chl} a$ ) and nutrients were collected using a Niskin bottle at 0,3,6 and $9 \mathrm{~m}$ (bottom) depth. Salinity and temperature were profiled using a CTD (Sensordata SD202). During the second sampling day, water samples were only collected at 4 sites at 0,3 and $9 \mathrm{~m}$ depth. Unfortunately CTD data was lost, and salinity was measured late on nutrient samples from discrete depths using a refractometer. 


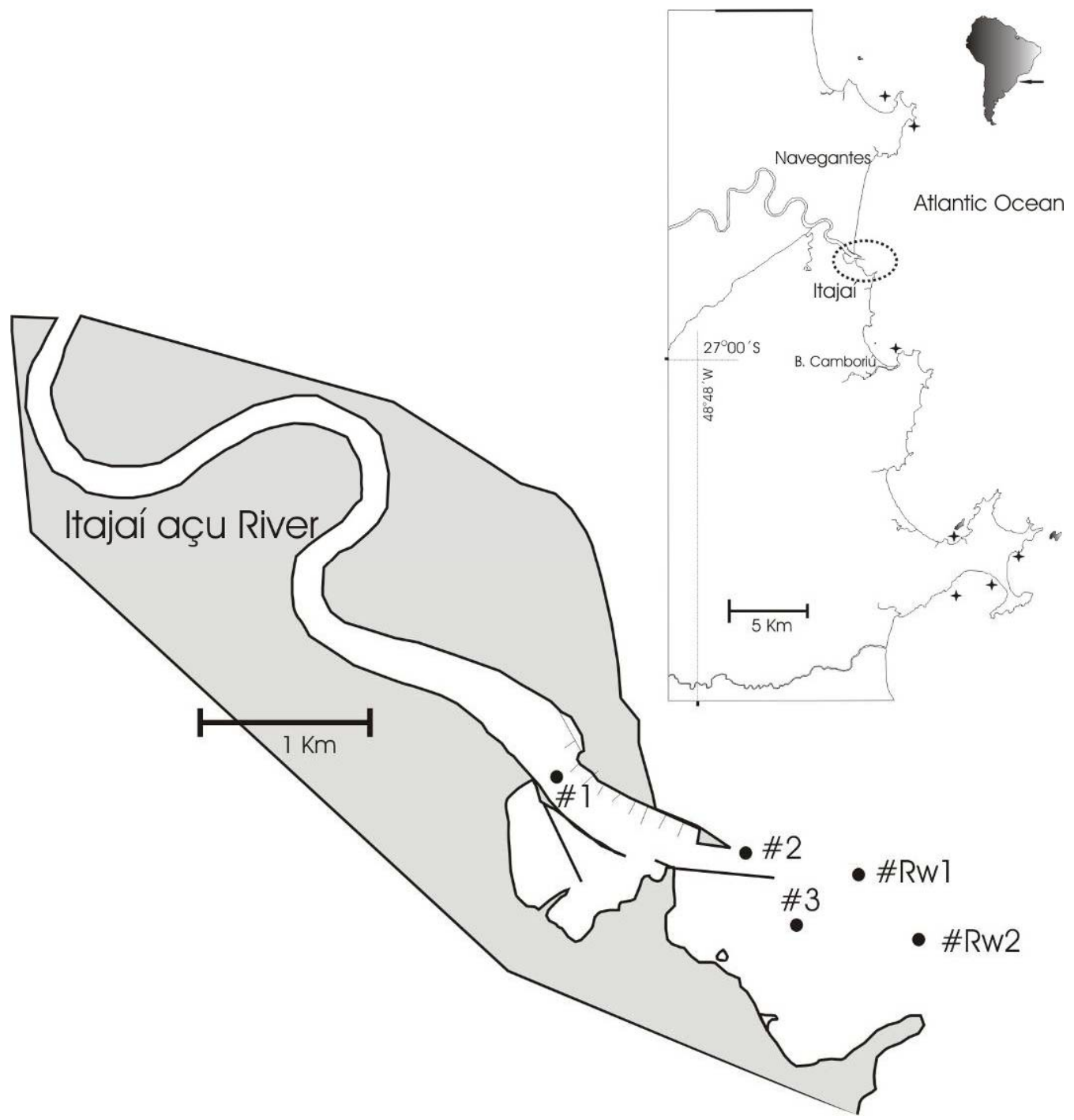

Fig. 1. Littoral central north littoral of Santa Catarina, showing sampling area (dotted circle), sampling sites and mussel culture areas $(\$)$.

Nitrate plus nitrite, ammonium and phosphate were analyzed by colorimetric methods according to Strickland \& Parsons (1972). Chl $a$ was determined on acetone extracts using sonication of the material retained on GF/C fiber glass filters $(2.5 \mathrm{~cm})$ by isocratic reversed phase high performance liquid chromatography (HPLC) analysis (Mantoura et al., 1997, modified by Proença, 2002). Chromatography was carried out in a Shimadzu system with fluorescence detection (FR551), using a ODS Shimpack column $(4.6 \times 40 \mathrm{~mm}, 3 \mu \mathrm{m}$ of particle size). The system, set to run for 4 minutes, was calibrated with pure Chl a and no attempts were made to characterize other pigments. For cell counts, samples were preserved in 1\% Lugol's iodine solution in amber glass bottles and enumerated by the inverted microscope technique (Utermöhl, 1958) using a $2.9 \mathrm{ml}$ sedimentation chamber. Cells were enumerated at $200 \mathrm{x}$ magnification in the whole chamber or its fraction, for samples taken outside and inside the red water, respectively.

The two days sampled showed different conditions despite being just seven days apart. Weather conditions changed after the passage of a cold front, from warm and calm days, not so typical of winter conditions, to cold and turbulent situation with 
southerly prevailing winds (Fig. 2), causing a drop in the average daily air temperature from 21.5 to 14.9 in 3 days. During the red water the water column was stratified with a surface temperature $\left(21.1^{\circ} \mathrm{C}\right) \quad 2.9$ degrees higher than at the bottom $\left(18.2^{\circ} \mathrm{C}\right)$ (Fig. 3A). The values for salinity were lower on the second day sampling, showing a greater riverine influence and changes in water column stability (Fig. 3B,C).

The first sampling day was characterized by heavy water discoloration with cell densities up to 4.4 $10^{6}$ cell $l^{-1}$ of $M$. rubrum (Fig. 4). M. rubrum was concentrated at the surface and decreasing with depth in the water column. Below the surface, cell number decreased to 0.1 and to $0.310^{6}$ cell $\mathrm{l}^{-1}$ at the sites located in the river and off the patch, respectively. Similar densities of $M$. rubrum were described in a red water event on the coast of São Paulo (Owen et al., 1992), but within a very vertically constrained patch $(30 \mathrm{~cm})$ associated to a thermocline. The concentration in a layer, as observed in São Paulo, is possible for this species due to it ability to swim and migrate within the water column. The maximum Chl $a$ measured was $66.8 \mathrm{\mu g} \mathrm{l}^{-1}$ at the site \#Rw2 (Fig. 5). Although this is a high value for the region (Proença 2002), it is well below the $1000 \mu \mathrm{g} \mathrm{l}^{-1}$, reported for upwelling systems (Smith \& Barber, 1979), but similar to those described in other reports on $M$. rubrum red water (Taylor et al., 1971, Lindholm, 1985, Crawford et. al., 1997, Owen et al., 1992).

Present data indicates that changes in the oceanographic conditions during the passage of a cold front were sufficient to cause the bloom dispersion. In general, the water column stability plays an important role in the red tide formation. $M$. rubrum, similar to dinoflagellates, has the ability to swim through the water column and concentrate in the surface waters causing water discoloration. Its behavior has been assumed to consist of an upward phototaxis, followed by downward migration, or dispersal, at night (Sousby et al., 1984). This ability was clearly shown in the red water described in São Paulo, where data showed that the red water was constrained within a $30 \mathrm{~cm}$ thick layer (Owen et al., 1992). Different factors, such as light penetration and the tidal cycle, may also affect its vertical distribution, as observed in the Southampton Water Estuary, where M. rubrum regularly causes red tides (Crawford \& Purdie, 1992). Synchronized vertical migration to the tidal cycle has been indicated to be a mechanism to avoid flushing from that estuary, where the red tide can persist for several weeks during the summer (Crawford et al., 1997).

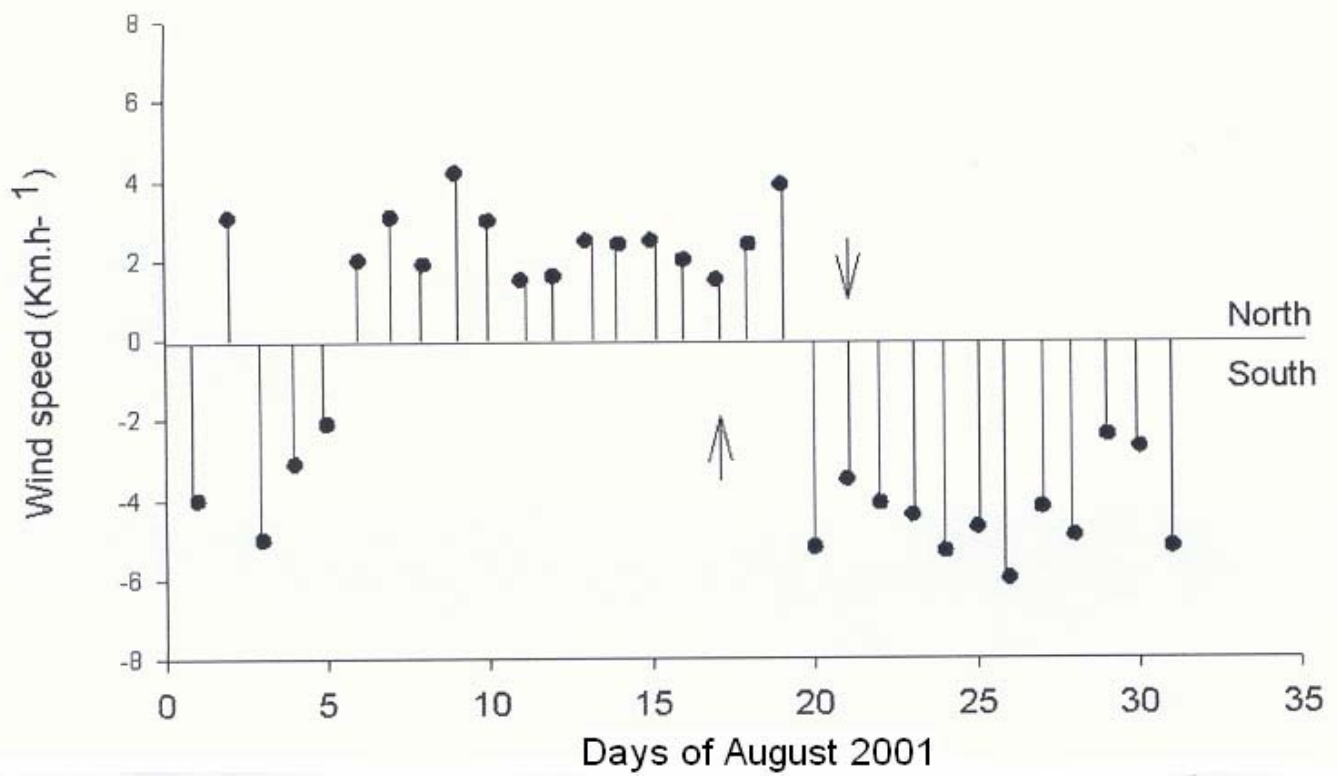

Fig. 2. Wind speed and predominant direction at Itajaí during August 2001. The arrows indicate data of sampling. 

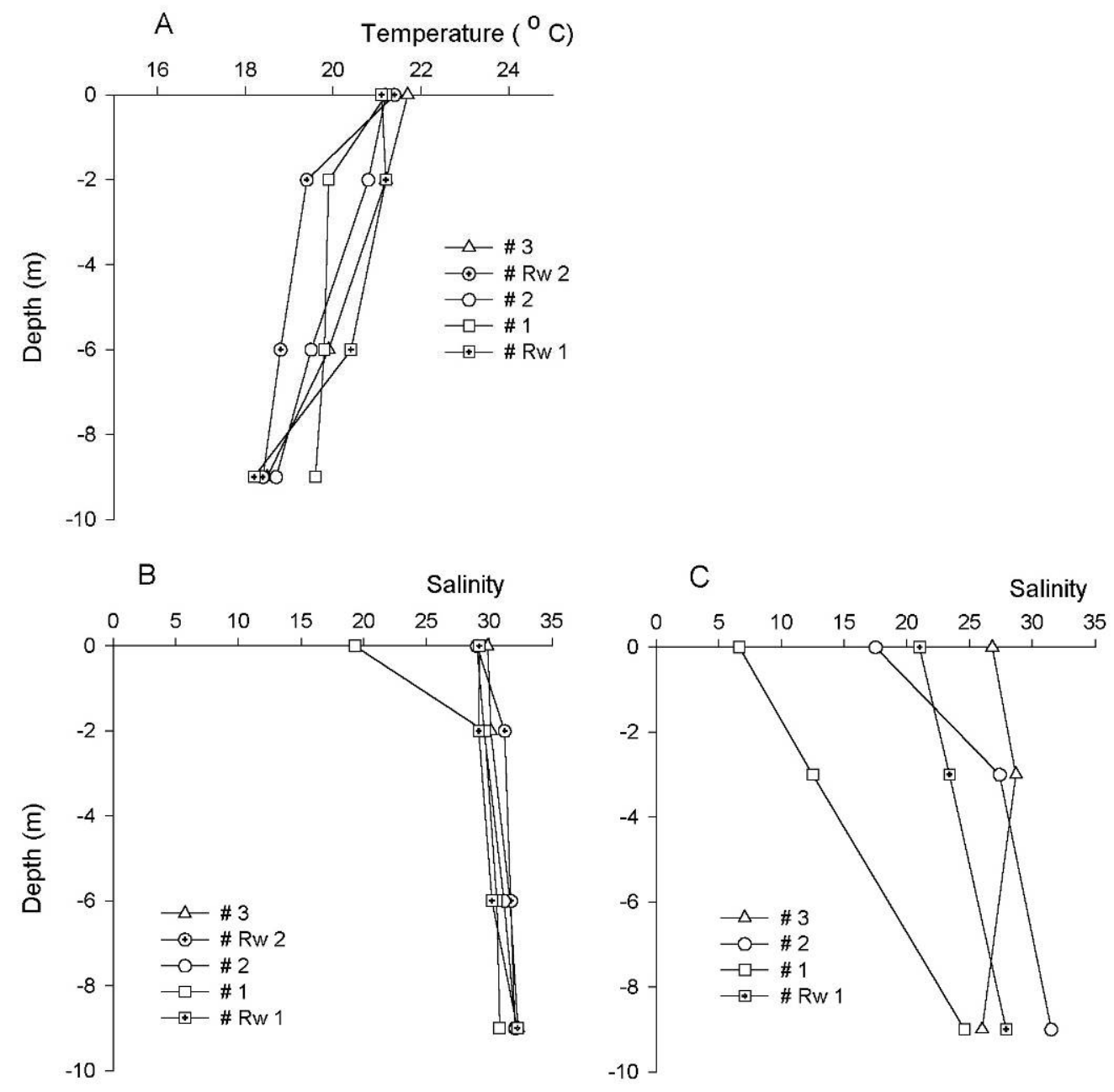

Fig. 3. Water temperature on August $17^{\text {th }}(A)$ and salinity profiles on August $17^{\text {th }}(B)$ and $24^{\text {th }}(\mathrm{C})$ at the sample points.

Nutrient concentration was lower during the bloom than after the passage of the cold frontal system (Fig. 6). It cannot be assured that lower values were caused by phytoplankton uptake because the short period of bloom stand and the environmental complexity of the region. The region is subject to severe changes according to other variables, such as runoff or tidal level, including sometimes the presence of a well-developed plume (Schettini et al., 1998). In Southampton Water, UK, where the bloom occurs for several weeks, $\mathrm{NH}_{4}{ }^{+}$is almost totally removed while some $\mathrm{NO}_{3}^{-}$persisted
(Crawford et al., 1997). During a red water event in São Paulo, vertical profile differences were not large, apart $M$. rubrum density and the presence of sharp thermocline (Owen et al., 1992). In that case, the relatively higher $\mathrm{NH}_{4}{ }^{+}$concentration value found at maximum $M$. rubrum layer was attributed to zooplankton excretion. In present, nutrient values found were similar to those previously observed in earlier works, even the high $\mathrm{NH}_{4}{ }^{+}$concentration (up to $44,18 \mu \mathrm{M}$ ) that has been associated to fresh water runoff and anthropogenic input (Pereira Filho et al., 2003). 

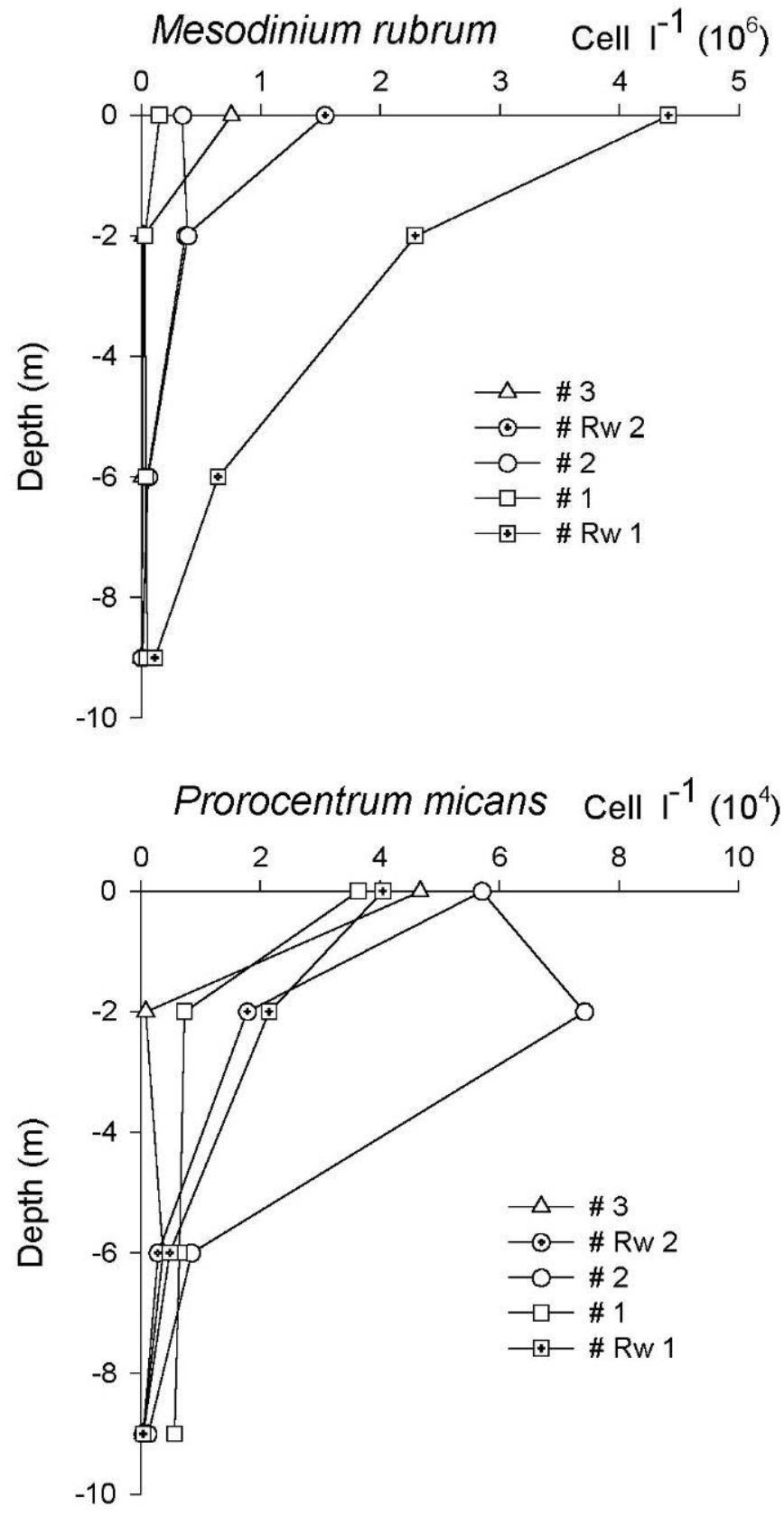

Fig. 4. Vertical profiles of cell count of Mesodinium rubrum and Prorocentrum micans during the red water on August $17^{\text {th }}$. 


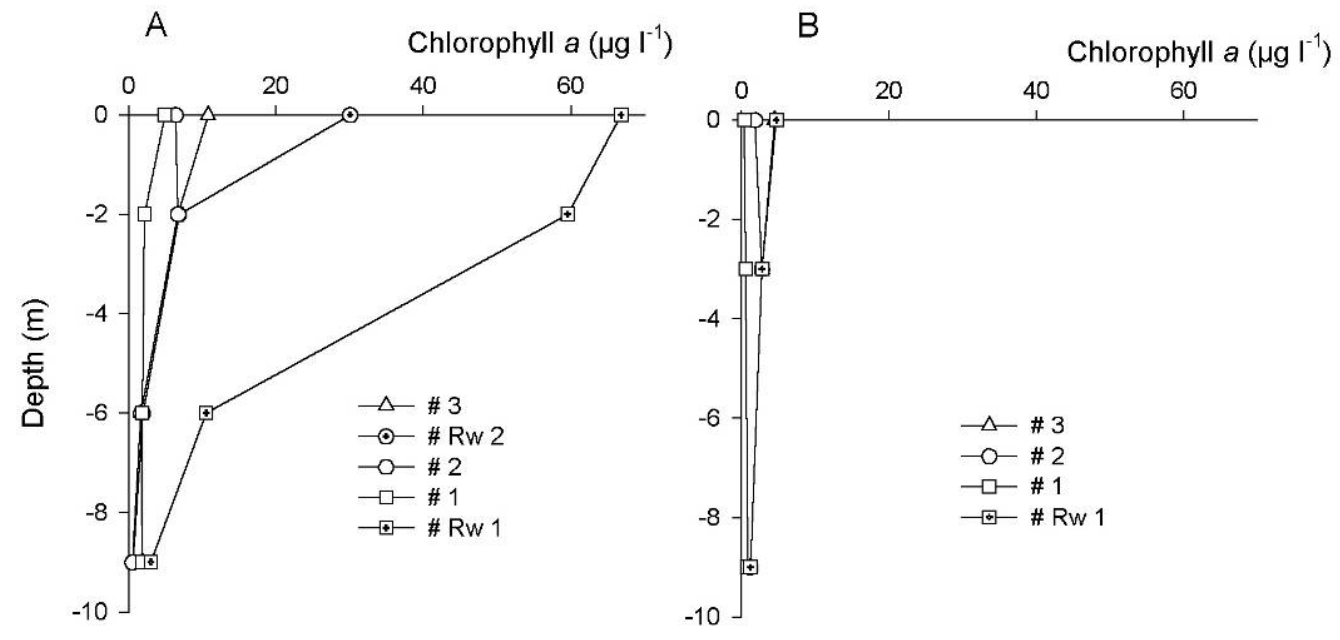

Fig. 5. Vertical chlorophyll $a$ profiles during the red water on August $17^{\text {th }}$ and after the cold front passage at sampled sites on $24^{\text {th }}$ August.

Principal component analysis applied to the data set summarizes the relationships among the observed variables (Fig. 7). The plot of the two main axes, which represented $67 \%$ of total variability, shows that biomass and cell densities were opposed to nutrients. Nutrients, on the other hand, were inversely related to salinity. The direct effect of the nutrient input associated to fresh water on phytoplankton biomass development is a common feature in coastal areas and have been observed in the region before (Proença, 2002).

The red water was not caused by a single species, as the dinoflagellate Prorocentrum micans also occurred in high numbers. P. micans is a cosmopolitan, planktonic, neritic species, with estuarine and oceanic distribution, commonly occurring in the studied area. $M$. rubrum was dominant only in the red water, while $P$. micans was present in surface waters of all sampled sites with relatively high numbers. In spite of being in side or outside the red patch, $P$. micans counts were always high, as $5.710^{4}$ or $3.610^{4}$ cell l $^{-1}$, respectively. In both cases, higher abundances were found closer to the surface. Other organisms also co-occurred in low densities, including diatoms, dinoflagellates and other ciliates, that were not identified.

Some algal blooms or red tides are associated with several sorts of harmful impacts to human or biota. Although there is no evidence for toxin production, a few harmful effects have been associated to $M$. rubrum, such as changes on water column properties, i.e. water oxygen depletion after bloom collapsing. Crawford et al. (1993) suggested that bacteria stimulated by blooms of the ciliate could affect wild oyster beds in the Solent, southern England. Descriptions of harmful impacts of $P$. micans blooms, which also occurred at high densities, are also rare. It has occasionally been associated with human shellfish poisoning or with aquatic organisms mortality, but potential toxins have not been identified (Landsberg, 2002). In the present event, no evidence of a harmful effect was observed.

Besides the dominance of these two species, relatively high densities of the dinoflagellates Dinophysis caudata and D. acuminata were also found. These species have been related with diarhetic shellfish poisoning, (DSP). DSP events have been identified in Santa Catarina (Proença et al., 1998) and $D$. acuminata pointed as one of the causative species (Proença et al., 1999). Although we did not analyzed the presence of okadaic acid or other toxins, if we consider the amount of $2.7 \mathrm{pg}$ of okadaic acid per cell (Proença et al., 1999) and the maximum of $D$. acuminata found at the red water $\left(2.4 \times 10^{3} \mathrm{cell} \mathrm{l}^{-1}\right)$, the toxin concentration would be around $6.5 \mathrm{ng} \mathrm{l}^{-1}$, indicating that mussels exposed to this condition would be contaminated with DSP toxins. 

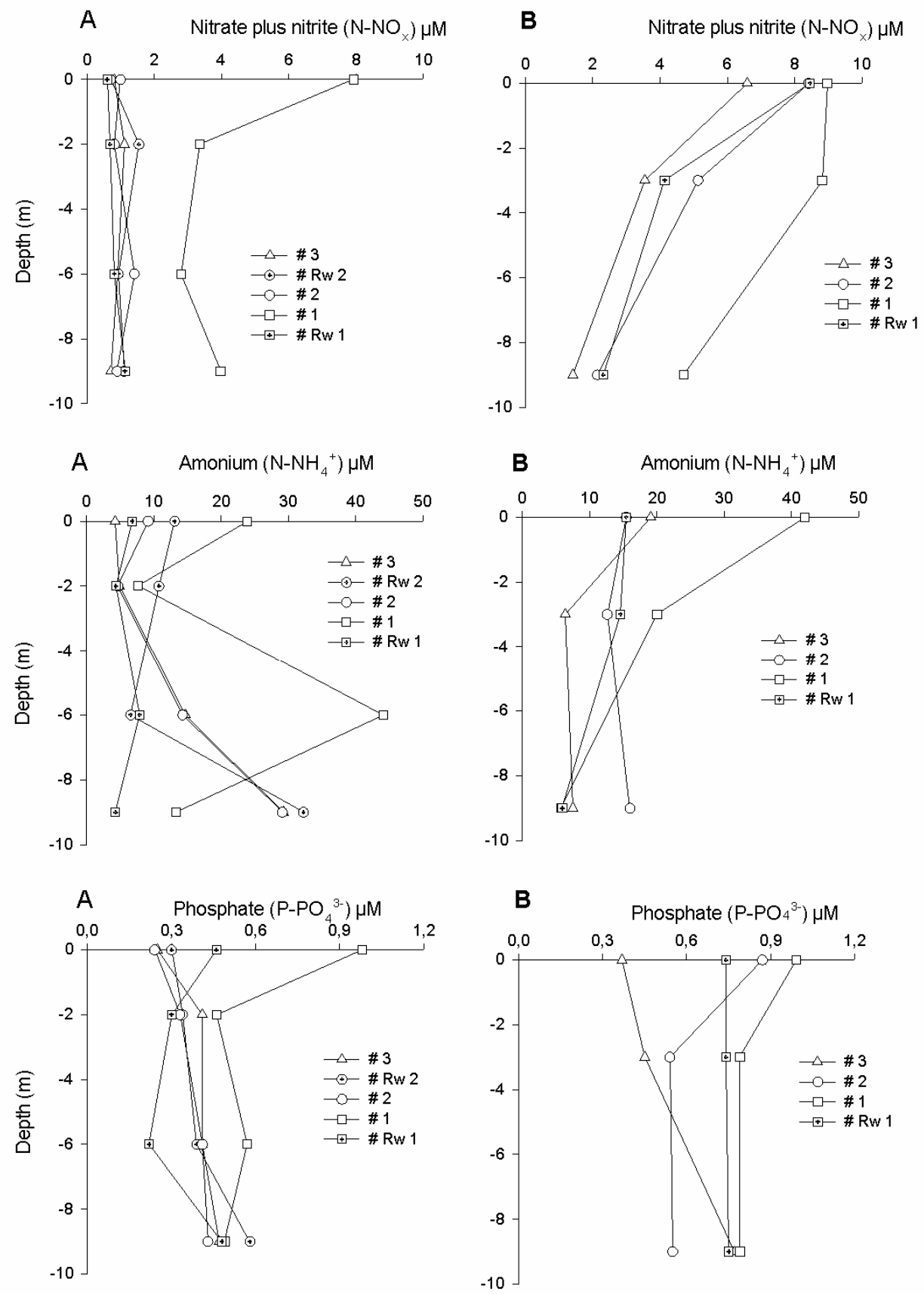

Fig. 6. Vertical inorganic dissolved nutrient profiles during the red water on August $17^{\text {th }}$ and after the cold front passage at sampled sites on $24^{\text {th }}$ August. 


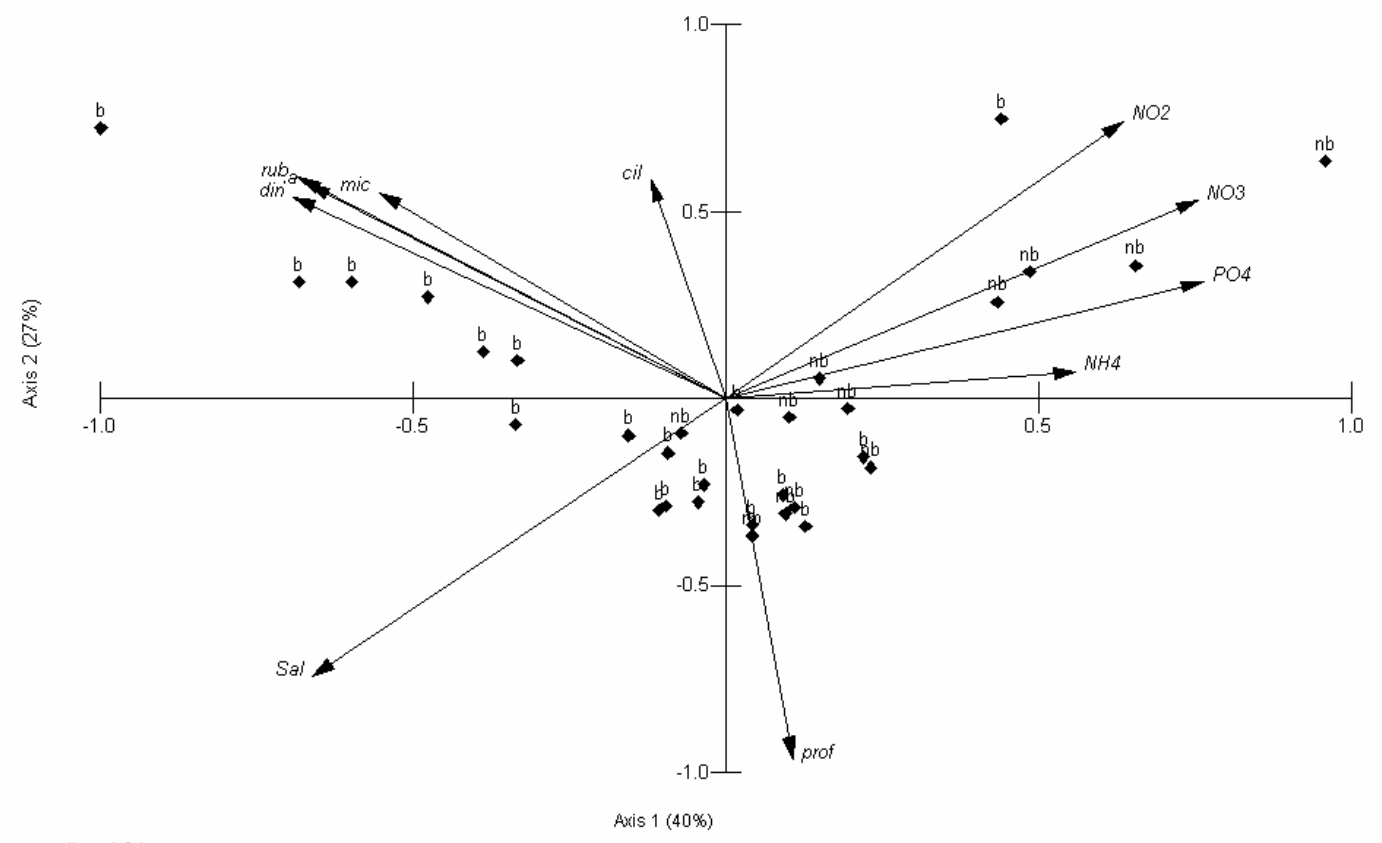

Vector scaling: 1,94

Fig. 7. Diagram of principal component analysis of the two main axes. (sal: salinity; prof: depth; din: Dinophysis spp; rub: Mesodinium rubrum; mic: Prorocentrum micans; cil: other ciliates; and nutrients. b: red water sampled on August $17^{\text {th }}$; nb: non red water sampled on August $24^{\text {th }}$ ).

This was the first report of red water caused by blooms of $M$. rubrum in the northern coast of Santa Catarina. Aerial survey showed that the red water extended in patches for more than $10 \mathrm{~km}$ along the shore, making this a conspicuous event. Other blooming species have been observed the since 1995 (Proença \& Rörig, 1995, Rörig et al., 1998, Proença et al., 1998). As several toxin producing algae have also been observed, the present results confirm the possibility of an occurrence of a toxic event associated to the Itajai-Açu estuary. The characterization and monitoring of algal blooms is important for the area, as a large mussel culture is located northwards, at Armação do Itapocoroy, and could be seriously affected by a toxic event.

\section{ACKNOWLEDGEMENTS}

To Marcio da Silva Tamanaha, Fabricio Schmitt and Luiz laureno Mafra Jr. for their aid in sample collection and processing. The paper benefited from comments by anonymous referees. The study was supported by the Centro de Ciências Tecnológicas da Terra e do Mar -CTTMar da Universidade do Vale do Itajaí.

\section{REFERENCES}

Abreu, P. C. 1992. Phytoplankton production and the microbial food web of the Patos Lagoon estuary, southern Brazil. PhD Thesis. Alfred-Wegener-Intitut für Polar- und Meeresforschung. 100p.

Crawford, D. 1989. Mesodinium rubrum: the phytoplankter that wasn't. Mar. Ecol. Progr. Ser., 58:161-174.

Crawford, D.; Hawkins, L. E.; Hutchinson, S.; Antai, E. E.; Purdie, D. A. \& Lockwood, A. P. M. 1993. Red tides of Mesodinium rubrum: evidence for remotely imposed stress on the oyster Ostrea edulis. In: Smayda, T. J. \& Shimizu, Y. eds. Toxic phytoplankton blooms in the Sea. Elsevier Science Publishers. London, p. 389-394.

Crawford, D.; Purdie, D. A.; Lockwood, A. P. M. \& Weissman, P. 1997. Recurrent red-tides in the Southampton Water estuary caused by the phototrophic ciliate Mesodinium rubrum. Estuar. Coast. Shelf Sci., 45:799-812.

Crawford, D. \& Purdie, D. A. 1992. Evidence for avoidance of flushing from an estuary by a planktonic, phototrophic ciliate. Mar. Ecol. Progr. Ser., 79:259-265.

Hibberd, D. J. 1977, Ultrastructure of the cryptomonad endosymbiont of the red-water ciliate Mesodinium rubrum: J. mar. biol. Ass., U.K., 57:45-61.

Landsberg, J. H. 2002. The effects of harmful algal blooms on aquatic organisms: Rev. Fis. Sci., 10:13-390. 
Lindholm, T. 1985. Mesodinium rubrum - a unique photosynthetic ciliate. Adv. aquat. Microbiol., 3:1-48.

Mantoura, F. A.; Jeffrey, S. W.; Llewellyn, C. A.; Claustre, H. \& Morales, C. E. 1997. Comparison between spectrophotometric, fluorometric and HPLC methods for chlorophyll analysis. In: Jeffrey, S. W.; Mantoura, R. F. C. \& Wright, S. W. eds. Phytoplankton pigments in oceanography. Paris, UNESCO. p. 361-380.

Odebrecht, C. 1988. Variações espaciais e temporais do plâncton (fitoplâncton, protozooplâncton e metazooplâncton) na Lagoa da Conceição. Ilha de Santa Catarina, Brasil. Atlântica, 10:21-40.

Odebrecht, C. \& Garcia, V. M. T. 1998. Ambientes costeiros e marinhos e sua biota: fitoplâncton, In Seeliger, U.; Odebrecht, C. \& Castello, J. P. eds. Os ecossistemas costeiro e marinho do extremo sul do Brasil. Rio Grande, Editora Ecoscientia. p. 117-121.

Owen, R. W.; Gianesella-Galvão, S.F. \& Kutner, M. B. B. 1992. Discrete, subsurface layers of the autotrophic ciliate Mesodinium rubrum off Brazil. J. Plank Res., 14(1):97-105.

Pereira Filho, J.; Spillere, L. C. \& Schettini, C. A. F. 2003. Dinâmica de nutrientes na região portuária do estuário do rio Itajaí-Açu, SC. Atlântica, 25(1):11-20.

Proença, L. A. O.; Schmitt, F.; Costa, T. \& Rörig, L. 1998. Just a diarrhea? Evidences of diarrhetic shellfish poisoning in Santa Catarina - Brazil. Ciência Cult., S Paulo, 50:458-462.

Proença, L. A. O.; Schmitt, F.; Silva, M.; Guimarães, S. \& Rörig, L. R. 1999. Produção de ácido okadaico, uma toxina diarréica, por Dinophysis acuminata em Santa Catarina. Atlântica, 19:121-127.

Proença, L. A. O. 2002. Clorofila $a$ do fitoplâncton em seis enseadas utilizadas para o cultivo de moluscos bivalves no litoral de Santa Catarina. Notas Tec. Facimar, 6:3344.

Proença, L. A. O. \& Rörig, L. 1995. Mussel production and toxic algal blooms in Santa Catarina State, Southern Brazil. IOC/UNESCO Harmful Algal News, 12/13:5.
Rörig, L.; Lugli, D. O.; Guimarães, S.; Proença, L. A.; Manzoni, G. \& Marenzi, A. 1998. Monitoração de microalgas planctônicas potencialmente tóxicas na área de maricultura da Enseada de Armação de Itapocoroy Penha - SC. Notas Téc. Facimar, 2:71-79.

Schettini, C. A. F.; Kuroshima, K. N.; Pereira Filho, J.; Rörig, L. R. \& Resgalla Jr., C. 1998. Oceanographic and ecological aspects of the Itajaí-açu river plume during a high discharge period. An. Acad. Bras. Ci., 70:335351.

Schettini, C.A.F.; Carvalho, J. L. B. \& Truccolo, E.C. 1999. Aspectos hidrodinâmicos da enseada da Armação do Itapocoroy. Notas Tec. Facimar, 3:99-109.

Smith, W. O. \& Barber, R. T. 1979. A carbon budget for the autotrophic ciliate Mesodinium rubrum. J. Phycol., 15:27-33.

Soulsby, P. G.; Mollowney, M.; March, G. \& Lowthion, D. 1984. The role of phytoplankton in the dissolved oxygen budget of a stratified estuary. Wat. Sci. Technol., 17:745-756.

Strickland, J. D. H. \& Parsons, T. R. 1972. A practical handbook of seawater analysis. Fish. Res. Board. Can., 167: 310p.

Taylor, F. J. R.; Blackbourn, D. J. \& Blackbourn, J. 1971. The red-water ciliate Mesodinium rubrum and its incomplete symbionts`: a review including new ultrastructural observations. J. Fish. Res. Bd. Can., 28:391- 407.

Utermöhl, H. 1958. Zur vervollkommung der quantitativen phytoplankton-methodic. Mitt. Int. Ver. Theor angew. Limnol. Oceanogr., 9:1-38.

(Manuscript received 28 July 2003; revised 10 February 2004; accepted 17 May 2004) 